\title{
Survei Minat Mengikuti Pelajaran Pendidikan Jasmani Olahraga dan Kesehatan
}

\author{
Ramlah*, Eko Hariyanto \\ Universitas Negeri Malang, Jl. Semarang No. 5 Malang, Jawa Timur, Indonesia \\ *Penulis korespondensi, Surel: ramlahrauf98@yahoo.com
}

Paper received: 3-5-2021; revised: 24-5-2021; accepted: 28-5-2021

\begin{abstract}
Abstrak
Minat merupakan daya tarik seseorang terhadap suatu objek sehingga mampu mengubah keinginannya, namun minat juga dapat dipengaruhi oleh beberapa faktor. Tujuan dari penelitian adalah untuk mengetahui minat di Madrasah Aliyah Negeri 1 Kota Malang terhadap pelajaran pendidikan jasmani olahraga dan kesehatan. Metode yang digunakan penelitian adalah survei dengan teknik pengambilan data menggunakan kuesioner lalu dianalisis menggunakan deskriptif kuantitatif. Hasil penelitian ini menunjukkan pada aktivitas dinyatakan tinggi, ketertarikan dalam kategori sedang, dan untuk perhatian dinyatakan tinggi, sarana dan prasarana tinggi, dan guru dinyatakan tinggi. Kesimpulan dari hasil penelitian ini adalah minat siswa mengikuti pelajaran pendidikan jasmani di Madrasah Aliyah Negeri 1 Kota Malang dikategorikan tinggi dan sedang.
\end{abstract}

Keywords: minat; pelajaran; pendidikan jasmani olahraga

\section{Pendahuluan}

Menurut Junaedi (2016) Pendidikan jasmani, olahraga, dan kesehatan merupakan bagian dari pendidikan nasional yang harus melibatkan unsur-unsur penting berupa pikiran dan tubuh. Pendidikan Jasmani Olahraga dan Kesehatan lebih besar memberikan kesempatan kepada peserta didik untuk memimpin dan dipimpin baik dalam kelompok atau diri sendiri (Darmawati, Rahayu, \& R.C, 2017). Berdasarkan pendapat di atas, dapat disimpulkan bahwa pendidikan jasmani bertujuan untuk mengembangkan berbagai macam keterampilan motorik, fisik, emosional, sosial dan moral serta meningkatkan kebugaran jasmani, sehingga pendidikan jasmani sangatlah penting untuk diterapkan dalam pendidikan.

Gunawan (2018) mengatakan bahwa minat adalah suatu unsur psikologi yang ada dalam diri manusia yang timbul karena adanya rasa simpati, rasa senang, rasa ingin tahu, dan rasa ingin memiliki terhadap sesuatu. Minat adalah suatu kecenderungan dari dalam diri individu yang menyebabkan individu tersebut tertarik atau menyenangi suatu situasi atau objek tertentu tanpa ada yang menyuruh (Gunawan, 2019). Minat belajar berpengaruh positif dan signifikan terhadap hasil belajar. Dengan demikian adanya peningkatan minat belajar maka akan diikuti oleh peningkatan hasil belajar. Artinya semakin baik minat belajar siswa, maka berdampak kepada hasil belajar siswa yang semakin baik (Nurhasanah \& Sobandi, 2019). Minat mendorong seseorang melakukan sesuatu untuk mencapai tujuan yang ingin dicapainya (Andriyanto, 2013). Minat adalah suatu kecenderungan dari dalam diri individu yang menyebabkan individu tersebut tertarik atau menyenangi suatu situasi atau objek tertentu tanpa ada yang menyuruh (Gujarat, 2020). Minat bukanlah jiwa yang berdiri sendiri, tetapi berinteraksi dengan gejala gejala jiwa yang lain seperti perhatian, motivasi, harapan, sumbersumber kecemasan, norma atau standar, kebutuhan dan keinginan (Rauf, 2019). Siswa berminat terhadap sesuatu maka siswa tersebut cenderung untuk member perhatian yang lebih besar terhadap sesuatu yang diminatinya dan mengikuti kegiatan yang dilakukan dengan 
rasa senang (Simbolon, 2014). Berdasarkan pendapat diatas dapat disimpulkan bahwa minat adalah suatu keinginan seseorang karena tertarik dengan objek.

Faktor yaitu internal dan eksternal yang mempengaruhi minat seseorang selain itu minat seseorang juga dapat dipengaruhi oleh orang-orang yang berada di lingkungannya memberikan motivasi sehingga minat akan tumbuh dari dalam diri seseorang. Berikut dapat diuraikan faktor internal dan eksternal minat yang diadaptasi dari (Indrawati, 2019). Faktor Internal a) Aktivitas merupakan titik sentral yang pokok dari segala bentuk perbuatan manusia. b) Ketertarikan sikap positif dan perasaan senang terhadap guru dan pelajaran tertentu akan membangkitkan dan mengembangkan minat siswa, sebaliknya sikap memandang mata pelajaran terlalu sulit atau mudah akan memperlemah minat belajar siswa. c) Perhatian minat timbul bila ada perhatian yang timbul dari dalam hati seseorang. Faktor eksternal a) Guru merupakan faktor yang penting pada proses belajar mengajar, cara guru menyajikan pelajaran di kelas dan penguasaan materi pelajaran yang tidak membuat malas. b) Sarana dan prasarana fasilitas yang kurang mendukung seperti buku pelajaran, ruang kelas, laboratorium yang tidak lengkap dapat mempengaruhi minat siswa begitu juga sebaliknya. Faktor yang mempengaruhi proses dan hasil belajar siswa baik itu faktor dari dalam, luar, maupun instrumen yang paling utama adalah minat, motivasi, dan guru (Aritonang, 2008). Dapat disimpulkan bahwa minat dipengaruhi oleh beberapa faktor.

Menurut Rismayanthi (2011) Pendidikan Jasmani Olahraga dan Kesehatan merupakan bagian integral dari pendidikan secara keseluruhan, bertujuan untuk mengembangkan aspek kebugaran jasmani, keterampilan gerak, keterampilan berpikir kritis, keterampilan sosial, penalaran, stabilitas emosional, tindakan moral, aspek pola hidup sehat dan pengenalan lingkungan bersih melalui aktivitas jasmani, olahraga dan kesehatan terpilih yang direncanakan secara sistematis dalam rangka mencapai tujuan pendidikan nasional. Pendidikan Jasmani Olahraga dan Kesehatan merupakan mata pelajaran yang melibatkan aktivitas fisik dan pembiasaan pola hidup sehat sehingga dapat merangsang pertumbuhan jasmani, kesehatan dan kesegaran jasmani, kemampuan dan keterampilan serta perkembangan individu yang seimbang (Supriatna et al., 2015). Pendidikan jasmani bukan hanya bertugas mendidik siswa dalam perkembangan dan pertumbuhan jasmani saja, namun penanaman sikap dan nilai-nilai hidup yang benar dapat ditanamkan melalui aktivitas jasmani (Wijaya, 2017). Pendidikan jasmani, olahraga dan kesehatan merupakan suatu proses pendidikan yang memanfaatkan aktivitas jasmani yang direncanakan secara sistematis, bertujuan untuk mengembangkan aspek kesehatan, aspek kebugaran jasmani, keterampilan gerak, keterampilan berpikir kritis, stabilitas emosional, tindakan moral dan penalaran (Winarno, 2016). Berdasarkan pendapat dari beberapa ahli dapat disimpulkan bahwa pendidikan jasmani adalah suatu pendidikan yang dapat mempengaruhi tumbuh kembang seseorang.

\section{Metode}

Metode penelitian yang digunakan adalah metode survei, dengan teknik pengambilan data menggunakan kuesioner, skor yang diperoleh dari kuesioner kemudian dianalisis menggunakan analisis deskriptif kuantitatif yang dituangkan dalam bentuk persentase. Sampel sejumlah 100 siswa. Tempat yang akan digunakan dalam penelitian ini adalah Madrasah Aliyah Negeri 1 Kota Malang pada tanggal 12 desember 2019 penelitian ini adalah penelitian non tes menggunakan instrumen penelitian yaitu kuesioner dengan skala likert. 


\section{Hasil dan Pembahasan}

\subsection{Hasil}

Hasil penelitian minat mengikuti pelajaran pendidikan jasmani olahraga dan kesehatan di Madrasah Aliyah Negeri 1 Kota Malang.

Tabel 1. Distribusi Frekuensi Minat dalam Aktivitas Mengikuti Pelajaran Pendidikan Jasmani di Madrasah Aliyah Negeri 1 Kota Malang

\begin{tabular}{ccccc}
\hline No & Interval & Frekuensi & Persentase (\%) & Kategori \\
\hline 1 & $21 \leq \mathrm{X}$ & 32 & $32 \%$ & Sangat tinggi \\
2 & $18-20$ & 33 & $33 \%$ & Tinggi \\
3 & $15-16$ & 23 & $23 \%$ & Sedang \\
4 & $12-14$ & 11 & $11 \%$ & Rendah \\
5 & $\mathrm{X} \leq 11$ & 1 & $1 \%$ & Sangat rendah \\
\hline Jumlah & & 100 & $100 \%$ & \\
\hline
\end{tabular}

Minat dalam aktivitas mengikuti pelajaran pendidikan jasmani di Madrasah Aliyah Negeri 1 Kota Malang adalah tinggi, dengan pertimbangan frekuensi terbanyak adalah pada kategori tinggi 33 siswa atau sebesar 33\%, kategori sangat tinggi 32 siswa atau 32\%, sedang 23 siswa atau 23\%, kategori rendah 11 siswa atau 11\%, dan kategori sangat rendah 1 siswa atau $1 \%$.

Tabel 2. Distribusi Frekuensi Minat dalam Ketertarikan Mengikuti Pelajaran Pendidikan Jasmani di Madrasah Aliyah Negeri 1 Kota Malang

\begin{tabular}{ccccc}
\hline No & Interval & Frekuensi & Persentase (\%) & Kategori \\
\hline 1 & $18 \leq \mathrm{X}$ & 14 & $14 \%$ & Sangat tinggi \\
2 & $14-17$ & 38 & $38 \%$ & Tinggi \\
3 & $10-13$ & 44 & $44 \%$ & Sedang \\
4 & $6-9$ & 4 & $4 \%$ & Rendah \\
5 & $\mathrm{X} \leq 5$ & 5 & $5 \%$ & Sangat rendah \\
\hline Jumlah & & 100 & $100 \%$ & \\
\hline
\end{tabular}

Minat dalam ketertarikan mengikuti pelajaran pendidikan jasmani di Madrasah Aliyah Negeri 1 Kota Malang adalah tinggi, dengan pertimbangan frekuensi terbanyak adalah pada kategori sedang 44 siswa atau sebesar 44\%, kategori tinggi 38 siswa atau 38\%, kategori sangat tinggi 14 siswa atau 14\%, kategori rendah 4 siswa atau 4\%, dan kategori sangat rendah 5 siswa atau $5 \%$.

Tabel 3. Distribusi Frekuensi Minat dalam Perhatian Mengikuti Pelajaran Pendidikan Jasmani di Madrasah Aliyah Negeri 1 Kota Malang

\begin{tabular}{ccccc}
\hline No & Interval & Frekuensi & Persentase (\%) & Kategori \\
\hline 1 & $18 \leq \mathrm{X}$ & 7 & $7 \%$ & Sangat tinggi \\
2 & $14-16$ & 43 & $43 \%$ & Tinggi \\
3 & $10-13$ & 40 & $40 \%$ & Sedang \\
4 & $6-9$ & 9 & $9 \%$ & Rendah \\
5 & $\mathrm{X} \leq 5$ & 1 & $1 \%$ & Sangat rendah \\
\hline Jumlah & & 100 & $100 \%$ & \\
\hline
\end{tabular}


Minat dalam perhatian mengikuti pelajaran pendidikan jasmani di Madrasah Aliyah Negeri 1 Kota Malang adalah tinggi, dengan pertimbangan frekuensi terbanyak adalah pada kategori tinggi sebesar 43 siswa atau sebesar 43\%, kategori sedang 40 siswa atau $40 \%$, kategori sangat tinggi 7 siswa atau 7\%, kategori rendah 9 siswa atau 9\%, dan kategori sangat rendah 1 siswa atau $1 \%$.

Tabel 4. Distribusi Frekuensi Faktor Sarana dan Prasarana Mengikuti Pelajaran Pendidikan Jasmani di Madrasah Aliyah Negeri 1 Kota Malang

\begin{tabular}{ccccc}
\hline No & Interval & Frekuensi & Persentase (\%) & Kategori \\
\hline 1 & $21 \leq \mathrm{X}$ & 15 & $15 \%$ & Sangat tinggi \\
2 & $16-20$ & 41 & $41 \%$ & Tinggi \\
3 & $12-15$ & 34 & $34 \%$ & Sedang \\
4 & $7-11$ & 9 & $9 \%$ & Rendah \\
5 & $\mathrm{X} \leq 6$ & 1 & $1 \%$ & Sangat rendah \\
\hline Jumlah & & 100 & $100 \%$ & \\
\hline
\end{tabular}

Faktor sarana dan prasarana minat mengikuti pelajaran pendidikan jasmani di Madrasah Aliyah Negeri 1 Kota Malang adalah tinggi, dengan pertimbangan frekuensi terbanyak adalah pada kategori tinggi 41 siswa atau sebesar 41\%, kategori sangat tinggi 15 siswa atau 15\%, sedang 34 siswa atau 34\%, kategori rendah 9 siswa atau 9\%, dan kategori sangat rendah 1 siswa atau $1 \%$.

Tabel 5. Distribusi Frekuensi Faktor Guru Mengikuti Pelajaran Pendidikan Jasmani di Madrasah Aliyah Negeri 1 Kota Malang

\begin{tabular}{ccccc}
\hline No & Interval & Frekuensi & Persentase (\%) & Kategori \\
\hline 1 & $62 \leq \mathrm{X}$ & 25 & $25 \%$ & Sangat tinggi \\
2 & $48-61$ & 53 & $53 \%$ & Tinggi \\
3 & $34-47$ & 21 & $21 \%$ & Sedang \\
4 & $22-35$ & 0 & $0 \%$ & Rendah \\
5 & $\mathrm{X} \leq 21$ & 1 & $1 \%$ & Sangat rendah \\
\hline Jumlah & & 100 & $100 \%$ & \\
\hline
\end{tabular}

Minat yang dipengaruhi faktor dari guru mengikuti pelajaran pendidikan jasmani di Madrasah Aliyah Negeri 1 Kota Malang adalah tinggi, dengan pertimbangan frekuensi terbanyak adalah pada kategori tinggi 53 siswa atau sebesar 53\%, kategori sangat tinggi 25 siswa atau $25 \%$, sedang 21 siswa atau $21 \%$, kategori rendah 0 siswa atau $0 \%$, dan kategori sangat rendah 1 siswa atau $1 \%$.

\subsection{Pembahasan}

\subsubsection{Aktivitas}

Aktivitas merupakan kegiatan dimana siswa melakukan berbagai macam kegiatan dalam pembelajaran sehingga pada minat mengikuti pelajaran pendidikan jasmani olahraga dan kesehatan di Madrasah Aliyah Negeri 1 Kota Malang dari hasil penelitian telah diperoleh berdasarkan frekuensi terbanyak adalah minat aktivitas mengikuti pelajaran pendidikan jasmani olahraga dan kesehatan di Madrasah Aliyah Negeri 1 Kota Malang kategori tinggi 33 siswa atau sebesar 33\%, pada minat aktivitas mengikuti pelajaran pendidikan jasmani olahraga dan kesehatan kategori sangat tinggi 32 siswa atau 32\%, minat aktivitas mengikuti 
pelajaran pendidikan jasmani olahraga dan kesehatan kategori sedang 23 siswa atau $21 \%$, minat aktivitas mengikuti pelajaran pendidikan jasmani olahraga dan kesehatan kategori rendah 11 siswa atau 11\%, dan minat aktivitas mengikuti pelajaran pendidikan jasmani olahraga dan kesehatan kategori sangat rendah 1 siswa atau 1\%. Hal ini dapat kita ketahui bahwa aktivitas siswa dalam mengikuti pelajaran pendidikan jasmani olahraga dan kesehatan adalah tinggi.

\subsubsection{Ketertarikan}

Ketertarikan sangatlah berpengaruh besar terhadap respon seseorang, Ketertarikan mengikuti pelajaran pendidikan jasmani olahraga dan kesehatan di Madrasah Aliyah Negeri 1 Kota Malang diperoleh dengan jumlah frekuensi terbanyak minat pada ketertarikan mengikuti pelajaran pendidikan jasmani olahraga dan kesehatan di Madrasah Aliyah Negeri 1 adalah dengan kategori sedang sebesar 44 siswa atau sebesar 44\%, minat ketertarikan mengikuti pelajaran pendidikan jasmani olahraga dan kesehatan kategori tinggi sebesar 38 siswa atau 38\%, minat ketertarikan mengikuti pelajaran pendidikan jasmani olahraga dan kesehatan kategori sangat tinggi sebesar 14 siswa atau 14\%, pada minat aktivitas mengikuti pelajaran pendidikan jasmani olahraga dan kesehatan adalah dengan kategori rendah sebesar 4 siswa atau $4 \%$, dan pada minat ketertarikan mengikuti pelajaran pendidikan jasmani olahraga dan kesehatan kategori sangat rendah sejumlah 5 siswa atau 5\%.

\subsubsection{Perhatian}

Perhatian mengikuti pelajaran pendidikan jasmani olahraga dan kesehatan di Madrasah Aliyah Negeri 1 Kota Malang menunjukkan nilai tertinggi yang diperoleh dengan jumlah frekuensi terbanyak minat pada perhatian mengikuti pelajaran pendidikan jasmani olahraga dan kesehatan di Madrasah Aliyah Negeri 1 Kota Malang adalah perhatian dikategorikan tinggi sebesar 43 siswa atau sebesar $43 \%$, perhatian mengikuti pelajaran pendidikan jasmani olahraga dan kesehatan kategori sedang sebesar 40 siswa atau 40\%, perhatian mengikuti pelajaran pendidikan jasmani olahraga dan kesehatan kategori sangat tinggi 7 siswa atau 7\%, perhatian mengikuti pelajaran pendidikan jasmani olahraga dan kesehatan kategori rendah sebesar 9 siswa atau 9\%, dan perhatian mengikuti pelajaran pendidikan jasmani olahraga dan kesehatan kategori sangat rendah 1 siswa atau 1\%. Berdasarkan pembahasan di atas dapat kita simpulkan bahwa minat pada perhatian mengikuti pelajaran pendidikan jasmani olahraga dan kesehatan di Madrasah Aliyah Negeri 1 Kota Malang dinyatakan tinggi sebesar 43 peserta atau $43 \%$, hal ini disebabkan besarnya respon siswa terhadap perhatian pada pelajaran pendidikan jasmani olahraga dan kesehatan.

\subsubsection{Sarana dan Prasarana}

Faktor sarana dan prasarana minat dalam mengikuti pelajaran pendidikan jasmani olahraga dan kesehatan di Madrasah Aliyah Negeri 1 Kota Malang hasil yang telah ditemukan dengan penelitian adalah untuk faktor sarana dan prasarana yang mempengaruhi minat dalam mengikuti pelajaran pendidikan jasmani olahraga dan kesehatan adalah kategori tinggi sebesar 41 siswa atau sebesar 41\%, faktor sarana dan prasarana minat dalam mengikuti pelajaran pendidikan jasmani olahraga dan kesehatan adalah dengan kategori sangat tinggi sebesar 15 siswa atau 15\%, faktor sarana dan prasarana minat mengikuti pelajaran pendidikan jasmani olahraga dan kesehatan dengan kategori sedang sebesar 34 siswa atau 34\%, faktor 
sarana dan prasarana minat mengikuti pelajaran pendidikan jasmani olahraga dan kesehatan pada kategori rendah sebesar 9 siswa atau 9\%, dan faktor sarana dan prasarana yang mempengaruhi minat mengikuti pelajaran pendidikan jasmani olahraga dan kesehatan kategori sangat rendah adalah 1 siswa atau 1\%. Sehingga dari pembahasan dapat disimpulkan bahwa faktor sarana dan prasarana mampu menarik minat mengikuti pelajaran pendidikan jasmani olahraga dan kesehatan di Madrasah Aliyah Negeri 1 Kota Malang sehingga berpengaruh besar terhadap minat siswa.

\subsubsection{Guru}

Faktor guru yang mempengaruhi minat dalam mengikuti pelajaran pendidikan jasmani olahraga dan kesehatan di Madrasah Aliyah Negeri 1 Kota Malang hasil yang telah ditemukan dengan penelitian ini adalah untuk faktor guru yang mempengaruhi minat dalam mengikuti pelajaran pendidikan jasmani olahraga dan kesehatan adalah tinggi, dengan pertimbangan frekuensi terbanyak pada kategori tinggi sebesar 53 siswa atau sebesar 53\%, faktor guru yang mempengaruhi minat dalam mengikuti pelajaran pendidikan jasmani olahraga dan kesehatan pada kategori sangat tinggi sebesar 25 siswa atau 25\%, faktor guru yang mempengaruhi minat dalam mengikuti pelajaran pendidikan jasmani olahraga dan kesehatan pada kategori sedang sebesar 21 siswa atau 21\%, faktor guru yang mempengaruhi minat dalam mengikuti pelajaran pendidikan jasmani olahraga dan kesehatan pada kategori rendah adalah 0 siswa atau $0 \%$, dan faktor guru yang mempengaruhi minat dalam mengikuti pelajaran pendidikan jasmani olahraga dan kesehatan pada kategori sangat rendah adalah 1 siswa atau 1\%. Dari pembahasan dapat disimpulkan bahwa faktor guru yang mempengaruhi minat mengikuti pelajaran pendidikan jasmani olahraga dan kesehatan di Madrasah Aliyah Negeri 1 Kota Malang dinyatakan pada kategori tinggi sebesar 41 siswa atau 41\%, berdasarkan frekuensi tertinggi.

\section{Simpulan}

Hasil faktor internal minat penelitian menghasilkan kategori pada faktor internal minat adalah aktivitas dinyatakan tinggi dengan 33 siswa atau 33\%, ketertarikan mengikuti pelajaran pendidikan jasmani olahraga dan kesehatan di Madrasah Aliyah Negeri 1 Kota Malang dinyatakan sedang sebesar 44 siswa atau 44\%, dan untuk perhatian mengikuti pelajaran pendidikan jasmani olahraga dan kesehatan di Madrasah Aliyah Negeri 1 Kota Malang dinyatakan tinggi 43 siswa atau 43\%. Faktor eksternal minat pada faktor sarana dan prasarana minat mengikuti pelajaran dinyatakan tinggi 41 siswa atau $41 \%$, dan untuk faktor yang berasal dari guru dalam mengikuti pelajaran pendidikan jasmani olahraga dan kesehatan di Madrasah Aliyah Negeri 1 Kota Malang dinyatakan tinggi 41 siswa atau 41\%. Berdasarkan hasil penelitian saran yang perlu disampaikan dalam penelitian ini sebagai berikut yaitu, mengembangkan penelitian lebih dalam lagi tentang minat siswa dalam mengikuti pelajaran pendidikan jasmani olahraga dan kesehatan, melakukan pengawasan pada saat pengambilan data agar data yang dihasilkan lebih objektif.

\section{Daftar Rujukan}

Andriyanto, T. (2013). Survei Pendidikan Jasmani, Olahraga, Dan Kesehatan Pada Satuan Pendidikan SD, SMP, SMA Negeri Se-Kecamatan Karangan Kabupaten Trenggalek. Jurnal Pendidikan Olahraga Dan Kesehatan, 1(1), 65.

Aritonang, K. T. (2008). Minat dan Motivasi dalam Meningkatkan Hasil Belajar Siswa. Jurnal Pendidikan Penabur, 7(10), 11-21. 
Darmawati, D., Rahayu, T., \& R.C, A. R. (2017). Leadership Guru Pendidikan Jasmani Olahraga dan Kesehatan di SMP Ogan Komering Ulu Timur Sumatera Selatan. Journal of Physical Education and Sports, 6(2), 108116. Retrieved from https://journal.unnes.ac.id/sju/index.php/jpes/article/view/17359

Gujarat, S. K. P. (2020). Survei Minat Siswa Mengikuti Pembelajaran Penjas Pada SMK Negeri 6 Makassar

Gunawan. (2019). Survei Minat Siswa Mengikuti Pembelajaran Penjas Pada SMA Negeri 22 Gowa. Doctoral Dissertation, Universitas Negeri Makassar.

Gunawan, F. (2018). Senarai penelitian pendidikan, hukum, dan ekonomi di sulawesi tenggara (cetakan pe; Gunawan \& Hastuti, eds.). Sleman: Deepublish.

Indrawati, F. (2019). Analisis Tingkat Berpikir Dan Minat Belajar Terhadap Kemampuan Pemahaman Konsep Dasar Mata Kuliah Trigonometri. Prosiding Seminar Nasional Pendidikan KALUNI, 2, 56-66. https://doi.org/10.30998/prokaluni.v2i0.27

Junaedi, A. (2016). Survei Tingkat Kemajuan Pendidikan Jasmani, Olahraga, dan Kesehatan Di SMA, SMK, dan MA Negeri Se-Kabupaten Gresik. Jurnal Pendidikan Olahraga Dan Kesehatan, 3(3), 834-842.

Nurhasanah, S., \& Sobandi. (2019). Motivasi belajar sebagai determinan hasil belajar siswa. Jurnal Pendidikan Manajemen Perkantoran, 4(1), 130. https://doi.org/10.17509/jpm.v4i1.14958

Rauf, A. (2019). Pendidikan Jasmani dan Olahraga Universitas Negeri Makassar.

Rismayanthi, C. (2011). Optimalisasi pembentukan karakter dan kedisiplinan siswa sekolah dasar melalui pendidikan jasmani olahraga dan kesehatan. Pendidikan Jasmani Indonesia, 8(April), 1-17.

Simbolon, N. (2014). Faktor Faktor yang Mempengaruhi Minat Belajar Peserta Didik. Elementary School Journal Pgsd Fip Unimed, 1(2), 14-19. https://doi.org/10.24114/ESJPGSD.V1I2.1323

Supriatna, E., Wahyupurnomo, A., Tanjungpura, U., Prof, J., Nawawi, H. H., \& Tenggara, P. (2015). Keterampilan guru dalam membuka dan menutup pelajaran pendidikan jasmani olahraga dan kesehatan di SMAN SeKota Pontianak. Jurnal Pendidikan Jasmani Indonesia, 11(1), 66-71.

Wijaya, F. (2017). Ketersediaan Sarana Dan Prasarana Pembelajaran Pendidikan Jasmani, Olahraga dan Kesehatan Di SMA Negeri Kabupaten Sumenep. Jurnal Pendidikan Olahraga dan Kesehatan, 5(2), 232235.

Winarno, M. E. S. (2016). Pengembangan Instrumen Penilaian Pengetahuan Mata Pelajaran Pendidikan Jasmani Olahraga dan Kesehatan (PJOK) Kelas XI Semester Gasal. Jurnal Pendidikan, 1(8), 1659-1664. 